\title{
SLC12A2 wt Allele
}

National Cancer Institute

\section{Source}

National Cancer Institute. SLC12A2 wt Allele. NCI Thesaurus. Code C102514.

Human SLC12A2 wild-type allele is located in the vicinity of $5 q 23.3$ and is approximately $106 \mathrm{~kb}$ in length. This allele, which encodes solute carrier family 12 member 2 protein, plays a role in cellular homeostasis. 